\title{
Correction: Yagüe, P., et al. Goals and Challenges in Bacterial Phosphoproteomics. Int. J. Mol. Sci. 2019, 20,5678
}

\author{
Paula Yagüe ${ }^{+} \mathbb{D}$, Nathaly Gonzalez-Quiñonez ${ }^{\dagger}$, Gemma Fernández-García, \\ Sergio Alonso-Fernández (D) and Angel Manteca *(D)
}

Área de Microbiología, Departamento de Biología Funcional, IUOPA, ISPA, Facultad de Medicina, Universidad de Oviedo, 33006 Oviedo, Spain; paula.yague@gmail.com (P.Y.); natygq@gmail.com (N.G.-Q.); gemmafg06@hotmail.com (G.F.-G.); sergioalonsofernandez@gmail.com (S.A.-F.)

* Correspondence: mantecaangel@uniovi.es

† These authors contributed equally to this work.

Received: 16 November 2020; Accepted: 24 November 2020; Published: 9 December 2020

The authors wish to make the following corrections to this paper [1]:

1. The author name "Gemma Fernánez-García" should be "Gemma Fernández-García".

2. Page 2, first line: "257 proteins" should be "301 proteins".

The authors would like to apologize for any inconvenience caused to the readers by these changes.

\section{Reference}

1. Yagüe, P.; Gonzalez-Quiñonez, N.; Fernández-García, G.; Alonso-Fernández, S.; Manteca, A. Goals and Challenges in Bacterial Phosphoproteomics. Int. J. Mol. Sci. 2019, 20, 5678. [CrossRef] [PubMed]

Publisher's Note: MDPI stays neutral with regard to jurisdictional claims in published maps and institutional affiliations.

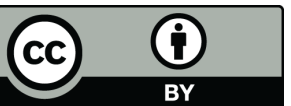

(C) 2020 by the authors. Licensee MDPI, Basel, Switzerland. This article is an open access article distributed under the terms and conditions of the Creative Commons Attribution (CC BY) license (http://creativecommons.org/licenses/by/4.0/). 